Sri Lanka Journal of Social Sciences 1999 22(1\&2): 63-76

\title{
THEATRE IN POLITICS AND POLITICS IN THEATRE: SRI LANKAN EXPERIENCE SINCE INDEPENDENCE
}

\section{MICHAEL FERNANDO}

Modern Sri Lankan Sinhala theatre, which is performed in the language used by $74 \%$ of the 18.7 million population of the South Asian island state Sri Lanka, emerged as a form of modern performing art by the mid-1940s. During a period of a little more than five decades, it has been transformed into a multifaceted and dymamic form of art that actively responds to the realities of Sri Lankan society and has become the most prominent component of the multi-lingual national theatre of Sri Lanka. Sri Lankan Sinhala theatre has tried not only to depict but also to take part in the socio-political developments in the country. The observation of the promiment American anthropologist Victor Turner (1985), that "the stage drama, when it is meant to do more than entertain -though entertainment is always one of its vital aims-is a metacommentary, explicit or implicit, witting or unwitting on the major social dramas of its social context (wars, revolutions, scandals, institutional changes)" seems to be very appropriate to describe the situation of the Sri Lankan Sinhala theatre since the country's achievement of political independence from British rule in 1948.

It is well-known that the ritualistic performances and the folk dramas of the Sinhalese and the first form of urban Sinhala theatre nurti. which emerged within the capitalistic socio-economic relations during the mid-nineteenth century, contained elements of social and political criticism of varying depths and degrees (Sarachchandra, 1966). Some nurti dramatists especially tried to use the stage drama as an instrument in the campaign against the British rule among the Sinhalese people (Jayawardene, 1972).

In this paper an attempt will be made to examine aspects of the inter-relationship between the socio-economic and political developments or in Turner's words "social drama" in the country and the modern Sinhala theatre during the past 50 years. 


\section{Socio-cultural and Political "Confusion" of a Newly Independent Asian Society Depicted on the Stage}

The first Sinhala play which made an attempt to depict the socio-cultural, and to a certain extent political realities of the post-independent Sri Lankan society was Bahinakalâva (Age of Decline) written and produced in 1951 by Ediriweera Sarachchandra who played the pioneering role in modernizing the Sinhala theatre. In this play written on the model of the European Naturalistic tradition, Sarachchandra was able to portray the confusion that prevailed in the newly independent Sri Lankan society, especially in regard to culture and cultural values. The policy followed by the state for the "revival" of national culture came under the playwright's ridicule and was exposed as hypocritical. The vacillation of a section of the society, especial.? the middle class, between the western and the eastern value systems and the nostalgic loyalty towards the British royal family and also the blind belief of another segment of the society aspiring to revive the ancient "prosperity" of the land including the purity of the language, were also depicted satirically.

Rejection of "Social Drama" as Content of Stage Drama and the Emergence of a Situation Conducive to a Politicized Theatre

The second phase of Sinhala theatre's transformation into a modern genre of performing art was consolidated by the mid-1950s as a result of the experiments and research carried out by the scholar-dramatist Sarachchandra himself. With his next play Pabawati, produced in 1952 he came to the conclusion that the main function of theatre should be the portrayal of "universal and timeless human problems", especially the "inner and deep contradictions of human behaviour" (Sarachchandra, 1955). According to him the main purpose of art is the experience of $a$ higher state of emotions or rasa, a concept borrowed from Sanskrit poetics. He developed a theory regarding the social function of art in general and suggested that even when art has to perform a didactic function it should act like a woman who tries to persuade a husband by implying her wishes in a very gentle manner and called it $k \hat{a} n t a \hat{s} s a m m i t a$. 
upadesha or lady-like instruction (Sarachchandra, 1955), using again a term used in Sanskrit poetics. These ideas of Sarachchandra had a deep impact on the generation of young dramatists who were also his students in the university.

On the other hand Sarachchandra vehemently rejected any form of state control over the arts and the commercialization of the arts (Sarachchandra, 1955). As a university teacher he initiated nonprofessional and self-sufficient touring-theatre groups consisting of university teachers, students and public and private sector employees, which have now become the foundation of the institutional framework of the Sri Lankan theatre. Even though Sarachchandra preferred not to discuss political problems in his plays this institutional framework established by him prepared a sound basis for a dynamic, independent and politically-oriented theatre that had the courage to stand up to repressive political tendencies and the effects of commercialization under market-economic conditions.

Sarachchandra and most of his followers continued to portray the "universal human problems" using the religious and folk stories of the Sinhala people in the stylized mode of representation which was introduced by Sarachchandra himself. He developed this style as an alternative to European Naturalism which, according to his observation, was not adequate to portray serious human problems on the Sinhala stage. ${ }^{7}$

\section{"Social Drama" Trickles on to the Stage}

As Sri Lankan Society was dragged into socio-economic and political turmoil after the second half of the 1950s, social drama in Turner's sense began to have an impact on the aesthetic drama as well. In the early 1960 s, several young playwrights attempted to bring social problems to the stage, paving the way for the politicization of the comparatively young modern Sinhala theatre. As expressed by some of the young dramatists, they wanted to portray the burning problems of the contemporary society instead of trying to depict only the universal 
human problems using the plots taken from traditional literature as their immediate predecessors were doing (Fernando,1984).

The majority of the pioneers of the politicized Sinhala theatre were talented young people who were employed in the government offices in Colombo, mostly at the secretarial level, in contrast to their immediate predecessors who came from a university environment. The subject matter of their first plays centered on the problems and sufferings of this group of workers harassed by their snobbish superiors, the stupid rules and regulations of the administration and the cut-throat competition among their colleagues. Their suppressed sexual aspirations and the hopeless conditions of the congested living quarters which were mostly rooms in private boarding houses in and around the city made their lives very miserable. Henry Jayasena in his Janêlaya (1961) and Tawat Udäsanak (1964), and Sugatapala de Silva in his Bôding Kârayo (1962). and Tattugeval (1964) were the first to successfully discuss these social problems on stage. These attempts were also combined with a search for an alternative to the stylized mode of representation developed by Sarachchandra. These led the dramatists to look for new vistas outside the country, and to a return to European Naturalism by dramatists like Sugatapala de Silva (Fernando, 1984).

\section{Politicized Drama}

After the initial experiments mentioned above, which were received by the critics as well as the general audience very enthusiastically, some of the Sinhala dramatists decided to discuss socio-cultural and political themes more comprehensively and in a bolder manner.

Institutionally, the Sinhala theatre had transformed itself by this time (mid-1960s) into a semi-professional tour-theatre based in Colombo and was able to reach an audience diverse in social class and level of literacy across the whole country. Besides, these semi-professional groups adapted themselves to perform in any kind of space, such as school halls in remote areas that offered only the minimum facilities. Furthermore, a group of volunteer players which called itself veedi nâtya kandâyama or "street players" was formed with the initiative of Gamini 
Hattotuwegama in 1974. They were geared to play in any place with just 'enough space for the movement of actors.

The themes discussed by the new generation of dramatists, mostly playwright-directors, varied from the current socio-cultural and political problems of the country to theoretical and practical problems of the social revolution. For example they tried to portray:

I. Specific worker, peasant and student struggles of the country;

II. Problems of adolescent school-goers;

III. Problems of slum dwellers;

IV. Problems created by the impact of an open economic policy;

V. Effects of tourism on the traditional culture of the country;

VI. The Brain drain;

VII. Unemployment among the educated;

VIII. Political insurrections which took place in the country during the recent past;

IX. Theoretical and practical problems of social revolution;

$\mathrm{X}$. General problems regarding capitalism and socialism;

XI. State and other forms of terrorism;

XII. Women who became victims of politics; and more recently,

XIII. The ethnic problem in which the whole country has been entangled for several decades.

It is interesting to note that, until very recently, no serious attempt was made by any of the Sinhala stage dramas to discuss the most dramatic event of the recent social and political history of Sri Lanka, the ethnic conflict between the Sinhalese and the Tamils. Apparently, they have avoided this piece of "social drama" due to lack of a clear vision. There seemed to be an ambiguity regarding the point of view from which this problem should be portrayed before a Sinhala audience. Paradoxically, the first Sinhala play which discusses an aspect of this complex conflict is a play (Tahanam Adaviya) written and produced by the young Tamil dramatist Visakesa Chandrasekaram in 1997. In this play, he portrays the dilemma of a 
generation of Tamil youth who joined a "liberation struggle" to find themselves trapped in a disintegrating fascist type of military organization where there was no way out other than to sacrifice their lives for an unclear cause. Chandrasekaram is a law graduate of the University of Colombo and a product of both Sinhala and Tamil cultures of the country by birth as well as by education. This background has certainly made him capable of looking at this problem from an impartial and humane point of view.

The veteran dramatist K.B. Herath also has made an attempt to discuss another aspect of the current civil war in his Deveni Mahinda, produced in the same year (1997). In this play he questions the legitimacy of a centralized political power structure as well as the sincerity of the demand for self government by provincial rulers. For this purpose, he uses a situation taken from 8th century Sri Lankan history portraying in the meantime the plight of women under such circumstances.

\section{Role of the Dramatist Changed}

In the process of attempting to portray these very complicated social and political problems, most radical young dramatists had to criticize and reject the main ideas put forward by the scholar-dramatists and critics regarding the purpose of art and the nature of its relationship with the spectator (in the case of theatre) and decided to use the theatre to achieve their goals in the economic and political spheres. Instead of the lady-like or kântâsammitta approach suggested by the scholar-dramatists, they started to experiment with a spectrum of approaches playing the roles of political philosopher, preacher, teacher, agitator, propagandist, revolutionary or even reporter.

\section{Inspirations from Outside}

The young dramatists who were experimenting to discuss contemporary political and social problems on stage turned towards the world theatre for inspiration. As already mentioned, they first looked at the outside world for a mode of representation suitable to portray 
contemporary themes on the stage. At the second stage their search became deeper. They wanted to draw inspiration regarding themes and a new aesthetic theory that could accommodate new attitudes. In this search they turned towards several dramatists such as Bertolt Brecht, Tennessee Williams, and the dramatists of the Theatre of the Absurd including Samuel Beckett, Eugene Ionesco, Julius Hay, Jean Paul Sartre and dramatists such as Peter Weiss, Friedrich Dürrenmatt and Dario Fo while showing a continued interest in Anton Chekov, Maxim Gorky and Henrik Ibsen.

By 1962 the Sinhalese dramatists such as Dayananda Gunawardene observed that they could find solutions for many of the problems they were facing by following Bertolt Brecht (Gunawardana, 1963). Since then he has become the main source of inspiration for them. Brecht's experiments were very useful to them regarding the form as well as the ideological approach of political theatre. From Tennessee Williams, and to a certain extent from the experiments of the director Elia Kazan, they seemed to have learnt new tecliniques for the portraying of contemporary life on stage (Fernando, 1984). It is interesting to note that some of the Sinhalese dramatists experimented very successfully with the methods used by the dramatists of the Theatre of the Absurd. However the majority of them rejected their world view and made use of their techniques to portray the problems of Sri Lankan Society from a Marxist and even Leninist point of view (Nawagattegama, 1974).

\section{"Social Drama" vs Stage Drama; Response of the Audience, Critics and the State Power}

As shown by the experience of Sri Lankan Sinhala theatre during the past five decades the portrayal of contemporary political themes on the stage has led to very complex and controversial situations.

When Henry Jayasena wrote and directed his Manaranjana Väda Varjana or "Cheerful Strikes" in 1966 based on one of the historical working class struggles of Sri Lanka it enraged the trade unions and the left parties of the country who took the position that the play distorted facts and ridiculed the heroes who sacrificed their lives in 
that struggle. One of the main office bearers of the organization that sponsored this production resigned from his office of this organization as a mark of protest (Jayasena, 1980). Jayasena wrote and produced another play Apata Pute Magak Näte (Son, we do not have a way out!) in 1968 , which was based on a true story of a university student who committed suicide. In this play he tried to portray the harshness of the methods used by the state to suppress student agitation, the immature nature of the student activities and the courage of the mother of the dead student. The officials of the Ministry of Education wanted to ban the play while the student movement protested to the playwright that it distorted facts regarding student activities in the universities.

When Sugatapala de Silva wrote and directed Dunna Dunugamuwe or "Weapons are out of reach" in 1972 he depicted the story of a strike from the point of view of a partisan and it became extremely popular and received long applause from the enthusiastic audience. The dramatist portrayed the company owners as an inhuman lot and the leader of the trade union as a positive hero who leads the strike to the end sacrificing even the life of his own child. The critics of the left oriented newspapers saw this play as a positive development in the Sinhala theatre. However the scholar-critics considered the portrayal of the character of the working class leader as unnatural and simplistic and questioned whether the applause received by the play was an appreciation of its artistic quality or simply a political reaction (Ayurapada, 1972).

One of the vivid examples of the conflict between "social drama" and stage drama in the Sinhala theatre since independence was the controversy created by the play Subha Saha Yasa by Simon Nawagattegama that was first staged in 1974. Material used by Nawagattegama for his play were Lenin's theses on revolution, the "fate" of the two Marxist parties participating in the coalition government in power and the defeat of the left extremist group (J.V.P) which attempted to overthrow the left-oriented coalition government in 1971 and a palace revolt which had taken place in the 1st century $\mathrm{AD}$ in Sri Lanka. As the playwright himself stated in this play he wanted to find answers to the following questions: 
1. How to present a revolutionary movement which has failed due to subjective reasons and due to the limitations of the objective historical situation?

2. Why do some revolutionary forces fail in spite of their sound class base?

3. Wherein lies the truth of the statement: "every revolutionary situation does not lead to a revolution; no revolution is possible without a correct revolutionary situation".

4. Would the achieving of political power alone bring liberation for the forces that stand behind such power? ${ }^{15}$

The play which is one of the most brilliant productions of the Sinhala theatre was received extremely well by the spectators across the country. However, the forces close to the government and the critics from the left parties saw it as a reactionary attempt that undermines the unity of the progressive forces of the country. One extremist group even agitated for the banning of the play.

By the mid-1970s the politicization of the Sinhala theatre took a new turn as a new generation of young dramatists started to write and direct a new kind of political play, the main purpose of which was agitation and propaganda. In a situation where the 1971 insurrection had failed and the people's hopes in the left-oriented coalition government were waning, these young radical artists tried to make open propaganda and agitation for a political revolution. The critics of the old school attacked these dramatists mercilessly and called them "instruments of bankrupt politicians" and their works as inappropriately bloated and empty (papadam nâtya) (Amaraselzara,1977).

One of the most significant and tragic developments of the conflict between "social drama" and the stage drama during the past two decades in Sri Lanka was the attempt made by those who were in power during the 1980s and early 1990 s to silence the dramatists who wanted to discuss political issues on the stage. This has resulted in several 
"disappearances" and at least one murder during the early 1990 s (Obeysekera, 1994).

\section{Estrangement and De-sensitization: Stage Drama Emerges Winner Over "Social Drama"}

Learning from their own experiments and also from the examples of dramatists like Brecht, several playwright-directors since the early 1980s tried to discuss social problems of contemporary Sri Lankan society without directly referring to particular individuals or groups of individuals in their representations. They were able to avoid a disturbing and harmful identification by using certain estrangement techniques.

One of the very few women playwrights of Sri Lanka, Somalata Subasinghe wrote and directed the play Vikruti or "Deformation" in 1982 which depicted the tragedy of a young girl who was pushed into the rat race of entering the medical school by her parents. In the Sri Lankan context this is a very sensitive problem and the avoidance of identification with many parents is almost impossible. However the dramatist enabled the parents to look at this problem from a new angle especially due to the estranging effect of the stylized form she used to portray this burning "social drama". Ranjith Dharmakeerti's Modara Mola (1982) and Jayalath Manoratne's Tala Mala Pipilâ (1985) were also examples of successfully avoiding harmful identification using a similar estrangement effect.

Sinhala dramatists have also used translations and adaptations of foreign dramatists and foreign or faceless backgrounds to depict very sensitive themes like state terrorism. This has helped them to avoid harmful identification and possible censorship as well. K.B. Herath, one of the leading dramatists of the country, discussed very tactfully the prevailing political oppression and the opportunism of religious leaders by presenting them against a Chilean background in his play Nâga Gurulâ (1991). Dharmasiri Bandaranayake, one of the most talented dramatists of the modern Sinhala theatre, portrayed the terrorism of the oppressor as well as the oppressed which was a 
significant feature of the Sri Lankan "social drama" of the day through his Dhavala Bhiishana(1991), a brilliant translation and production of Jean Paul Sartre's Men Without Shadows.

Sri Lankan society experienced an unprecedented "social drama" in the form of a wave of horror during the late 1980s and early 1990 s. A large number of indiscriminate murders and counter-murders committed by the government, a rebel group in the south and the Tamil rebels in the north led to a situation which crossed the borders of a political conflict and became a sadistic exercise by groups of individuals who seemed to have enjoyed the brutal killings as a means of entertainment. In one instance a decorative pond in a prominent place inside a university campus was decorated with the severed heads of young people killed by pro-government death squads. Under such circumstances, the Sinhala theatre acquired a new legitimacy among the population. The critics of the old school and the section of the audience who preferred a theatre without politics seemed to have become "de-sensitized' to a politicized theatre and even came out in favour of it. Gunadasa Amarasekera the old school critic who mercilessly attacked the young dramatists in 1977 accusing them for becoming instruments of bankrupt politicians not only confessed his "errors" but also himself wrote the play Kavandhayake Katandaraya in 1992 portraying the "social drama" of the day (Amarasekara, 1992).

\section{The Plays that Came too Late?}

Bertolt Brecht made the following note in 1954, six years after the first staging of his anti-war play Mutter Courage und ihre Kinder: "It is certainly a brilliant production, with great actors. Undoubtedly something has changed. The play is no longer a play that came too late, that is after a war (Brecht, 1967).

By mid-1990s the socio-political situation in Sri Lanka changed radically. The "reign of terror" which prevailed in the southern part of the country came to an end. However, the attempt to bring the ethnic war to and was not successful and the civil war continued to be the 
burning problem in the country. Under this changing situation of "social drama" in the country, the stage drama which was geared to a different environment seemed to have faced a situation similar to the one described by Brecht regarding his 1949 production of Berlin Mutter Courage. The immediate "victim" of this most welcome political process in the country was Yakshâgamanaya, a translation of Brecht's Arturo Ui by Sunil Wijesiriwardene which was brilliantly directed by Dharmasiri Bandaranayake. This production would have been extremely effective if it was staged before 1993. At the time the play was staged, however, the "gangster" and the "gangsterregime" about which the Sinhala dramatists wanted to warn the Sinhala audience were no more. A play which was very successful in portraying the "social drama" of the day in detail, K. B. Herat's Nâga Gurulâ too lost its relevance to a certain extent, although not completely, after 1994.

\section{Conclusion}

The Sri Lankan experience in discussing the socio-economic and political events on the stage or, in Victor Turner's words, the "social drama", shows several significant features compared with the theatres of the countries of other parts of the world.

Firstly, political drama has become an integral part of the mainstream Sinhala theatre. The resistance from the dramatists and critics who opposed politicization of the Sinhala theatre has waned and some of the exponents of a non-political theatre have been converted into champions of political theatre. The nature of the composition of the audience and the absence of a commercialized professional theatre seem to be the main causes of this situation. However it should also be mentioned that the "non-political" plays written and produced by Sarachchandra still play a very important role on Sri Lankan stage even after several years of his death.

Secondly, the institutional framework of the Sinhala theatre based on semi-professional, self sustained touring-groups has led to an independent artists' theatre free not only from the influence of 
finance capital but also from state control. In other words, Sinhala theatre has been able to overcome the ill effects of a market-economy as well as the limitations of an under-developed political culture. This situation has given the author-directors of the Sinhala theatre the freedom of portraying the "social drama" of the country while facing only a minimum risk.

Finally, the playwright-directors of the Sinhala theatre seem to have found the modes and techniques of portraying current "social drama" of the country on the stage very effectively. Thus they are not only able to avoid an unnecessary and harmful identification but have also been successful in initiating critical attitudes in an audience that is also an integral part of the "social drama".

\section{References}

Amarasekara, Gunadasa (1977). Papadam Nâtya Kalâven Tharunayan Bêra Ganimu, In: Aththa 12th June, p.2

Amarasekara, Gunadasa (1992). Kavandayake Katandaraya, Colombo: p.6

Ayurapada (1972). Daruwan Dandima, In: Rupana April-June , p.39

Brecht, Bertolt (1967). Gesammelte Werke. Frankfurt am Main, Suhrkamp Verlag, p.1147

Fernando, Michael (1984). Die Singhalesishe Bühne und Bertolt Brecht, Berlin: Brecht Zentrum, pp.85-86

ibid, pp.85-87

ibid, pp 101-113

Fernando, P. (1974). In: Some Thoughts on Subha Saha Yasa, Ceylon Daily News, 25th June, p.4 
Gunawardana, Dayananda (1963). Naribäna, Colombo: p.13

Jayasena, Henry Facts disclosed at an interview with the author of this article in 1980 .

Jayawardene, V.K. (1972). The Origins of Labour Movevement in Sri Lanka, Durham: North Carolina, p.96

Nawagattegama, Simon (1974). The play Subha Saha Yasa

Obeysekera, Ranjini (1994). The Sinhala Theatre of the Eighties In: The Sri Lanka Journal of Humanities, Vol. XVII and XVIII, Numbers 1 and 2) University of Peradeniya pp. 75-90

Sarachchandra, Ediriweera (1955). Pabavathi, Colombo, pp. 37-38

Sarachchandra, Ediriweera (1958). Kalpanalokaya, Maharagama: Saman Publishers, pp.47-62

ibid, pp.6-9

Sarachchandra, Ediriweera (1958). Maname, Maharagama Saman Publishers, p.18

Sarachchandra, Ediriweera (1966). The Folk Drama of Ceylon, Colombo: Department of Cultural Affairs, pp.25-84

Turner, Victor (1985). From Ritual to Theater, New York: Performing Arts Journal Publications, p. 117 